\title{
Editorial: Neglecting Elders in the Workplace: Civil Society Organizations, Ageism, and Mandatory Retirement
}

\section{Introduction}

In Lucino Visconti's 1971 film, Death in Venice, a middle-aged composer falls for a beautiful adolescent boy. The movie's opening scene limns a powerful contrast between the ill-fated impresario and a muscular longshoreman in his seventies, who loads the agonized tourist's massive luggage and advises him about a deceptive gondolier. Visconti's magical sequence captures the proudly independent elder worker still possible at the dawn of the industrial age, when a large majority over 65 were employed, and also during the film's own period, before the insidious mixture of retirement ideology and ageism purged most older employees from places of work.

I want to probe the inadequate response of civil society organizations $(\mathrm{CSOs})^{1}$ to the astonishing, century-long evaporation of elder workplace voices. Let me start with a striking example. In New Orleans, the levee system's failure after Hurricane Katrina had devastating effects on older citizens, who suffered disproportionately from drowning, malnutrition, dislocation, disease, and property loss. Yet, the website of the Sixth International Conference on Diversity in Organisations, Communities and Nations (2006) - also affected by the storm (it had to switch its venue from flood-damaged Xavier University to the Sheraton New Orleans Hotel)omits age in its definition of difference ("ethnicity, gender, race, socio-economic, indigenous, religion, gender [sic], sexual orientation, disability" are highlighted categories) and, at the conference itself, no presentations or discussion groups were devoted to elders. Halfway across the continent, the 2006 Congress of the Canadian Federation for the Humanities and Social Sciences occluded age from its section on "equity" and a featured list of dozens of papers dealing with women's issues neglects the topic, though a sizeable majority of elders are women.

These are not anomalies, but standard instances of the rule that employment equity and diversity concerns within civil society have minimal traction for those beyond age 60 or 65 . The United States leads in fighting ageism, mostly because of the American Association of Retired Persons (AARP) and the U.S. Equal Economic Opportunity Commission-which administers the Age Discrimination in Employment Act (ADEA). But only a quarter of U.S. workers over 65 are employed (indeed the ADEA does not apply to executive suites, where retirement at 65 or earlier is expected). Government agencies supporting older workers (such as human rights commissions) and age advocacy organizations in other developed countries are extremely weak or non-existent. (Most state organs dealing with "seniors" focus on how to assist vulnerable older individuals to compensate for frailties.)

\section{The Law and Mandatory Retirement}

There are no laws requiring mandatory retirement; the practice relies on the absence of legal protection for older workers from discrimination by employers and unions. Forced retirement's most ardent practitioners include universities-supposed defenders of equity and social justice. When the United States abolished mandatory retirement in 1986, the postsecondary sector waged a vigorous campaign for exemption. The Age Discrimination in Employment Act finally took hold in 1994, and American colleges launched (still continuing) early retirement programs and bonus schemes to squeeze out aged professors. If carrots do not work, administrators brandish sticks. Accordingly, the University of Maryland at College Park this year removed 75-year-old Daniel Leviton from his popular and unique senior-level course (on dying and grief), and ordered him to teach freshmen offerings instead-a discouragement ploy practiced in other colleges (see "Hell, No-He Won't Go", 2006).

Much anticipated European Union legislation promising to ban compulsory retirement by 2006 turned out to have national exception clauses easily negotiable by a five-ton lorry. Faced with obstreperous opposition from the powerful Confederation of British Industries, which mounted a "work-till-you-drop" publicity campaign, the Blair government last December set aside its plans to enforce workplace 
rights past age $65 .^{2}$ While older person's advocacy organizations such as Age Concern vainly protested, most British civil society groups remained silent.

In Canada, excepting Manitoba and Quebec (both provinces abolished forced retirement in the early 1980s), workers face an array of mandatory retirement policies. Seconded by the Canadian Union of Public Employees, for example, the Saskatoon Public Library fired part-time librarian Louise Carlson in 2003 on account of age. Her case is now wending its way through the labyrinthine Saskatchewan Human Rights Tribunal (see Saskatchewan Human Rights Tribunal, 2005). The University of Lethbridge will soon axe Ian Whishaw, its Board of Governors Chair of Neuroscience, for having too many birthdays (University of Alberta et al., 2005.). While promising to heed the recommendations of its Human Rights Commission (which about-faced on mandatory retirement in 2004) (see New Brunswick Human Rights Commission, 2005), the New Brunswick government has still not introduced legislation to eliminate the practice.

The Ontario government launched consultations to eliminate mandatory retirement in fall 2004. Early the next year, the University of Toronto abolished forced exit, amid a severe shortage of job applicants and loss of older professors to rival Anglo-American institutions (New Zealand and Australia halted compulsory retirement in the 1990s). The Toronto agreement likely encouraged Queen's Park to ignore feverish demands from the university sector for an exemption from legislation to eliminate forced retirement (but the Ontario government allowed a one-year grace period before proclamation of the legislation on December 12, 2006.).

The Ontario initiatives will likely re-ignite Canada's struggle against age discrimination, after a 15-year hiatus imposed by Supreme Court cases involving librarians, physicians, and university professors. In the disastrous 1990 McKinney decision, learned judges ruled against-among others-Bernard Blishen, Research Director for the Hall Commission that established Canada's medicare system and key founder of sociology in Canada. A 67-year-old jurist sentenced Métis scholar Olive Dickason in the 1992 Dickason judgement. At age 50 Dickason joined the University of Alberta and single-handedly established the discipline of aboriginal history. Now 86, Dickason is still troubled by the decision; she recently observed "that the policy [of mandatory retirement] tends to hurt women more than men, since they raise families before becoming PhD graduates" (cited in "U of A Rethinks Policy on Mandatory Retirement," 2006).

\section{Canadian CSOs and Mandatory Retirement}

Robert N. Butler's classic Why Survive? (1975) dealt strongly with workplace mistreatment of U.S. elders, and Martin Lyon Levine's elegant Age Discrimination and the Mandatory Retirement Controversy (1988) contextualized the issue for Americans. But one has to go back to Daniel Jay Baum's The Final Plateau (1974) to discover a powerful Canadian blast against workplace age discrimination. ${ }^{3}$ The issue of ageismeven the word itself-is virtually absent from Canada's union movement. A federal study revealed that "most unions support-or at least acceptmandatory retirement as a means of giving job opportunities (i.e., promotions) and job security (i.e., fewer layoffs) to their younger members. This is especially true during periods of economic downturn" (Fourzly \& Gervais, 2004).

Following a similar pattern in other developed countries, most CSOs in Canada, including human rights and civil liberties organizations, offer slight opposition to compulsory retirement. When a 74-yearold professor battled forced retirement from the University of Winnipeg last year (some Manitoba universities now practice compulsory retirement thanks to an exemption for post-secondary institutions granted in the mid-1990s) a "human rights specialist" led the case against him (Macafee, 2006). Research featured by the progressive think tank the Canadian Centre for Policy Alternatives (CCPA) (2006) is mostly silent on ageism. ${ }^{4}$

Like their American counterparts, Canadian feminist organizations may lack a position on ageism. (The U.S. National Women Studies Association explored the issue of ageism for the first time in its landmark 2005 Convention; elsewhere in the landscape of U.S. feminism, elder women are nearly invisible [see Marshall, 2006].) The Women's Legal Education and Action Fund (LEAF) (n.d.[a]), which monitors the impact of the Canadian Charter of Rights and Freedoms on women's equality, lists no action against compulsory retirement among its significant cases (though on its Web site there is a special section for "Teens" [see LEAF, n.d.(b)]). LEAF's "Submissions to the Canadian Human Rights Review Panel, November 1999" did not broach forced exit, though it did note that women are often assigned "the role of unpaid caregiver for children, men and old people" (LEAF, 1999, p. 24).

Insufficient awareness of ageism within feminist and other CSOs has extremely harmful consequences, not only within the ambit of these organizations, but also throughout the wider social communities they influence. Without such recognition in academia, 
for instance, there is a limited basis for theorizing ageism and for determining the conditions necessary for liberating elders from society's harsh constraints (Liscomb, 2006).

\section{Prospects for Elder Workplace Equality}

The modern institution of retirement may bear central responsibility for our contemporary ideology of aging as inevitable decline and deterioration. Remarkably, the great retirement experiment has generated little research or public reflection about "what life in old age ought to be about" (Achenbaum, p. 50). Nevertheless, an overriding theme in Western philosophy is the value of labour for the human spirit. Straining human capacity against the external world to satisfy social needs contributes to individual health and growth, at any age. Bonnie Rooks, at age 78 the oldest steelworker in the United States, is employed in a physically demanding workplace not only because she needs the money for her disabled daughter but because of the meaning of work. "She worries about what she's going to do if she quits. 'I'm lucky, I have a lot of young friends,' she says. 'But they are going to be working and I don't know what I'm going to do with myself'" ("At 78, Bonnie Rooks Likes a 'Dirty Old Job' in an Ohio Steel Mill", 2005).

In contrast with most civil society organizations, government and industry policy bodies have come to appreciate the tremendous societal losses that may be incurred by cutting elder workers adrift (see, e.g., Organisation for Economic Cooperation and Development, 2005-not only the need for financial support of a multitude of retirees who may live a further 20 or 30 years, but also the potential labour market shortages associated with the profligate waste of the skills and knowledge of older employees in a rapidly aging work force.

A new workplace program would promote job flexibility and greater autonomy for every worker, old or young. It would encourage longer working lives by combating ageist stereotypes that are certain to linger well after compulsory retirement is gone. Employers would provide promotional and training advantages to workers, regardless of age. To help effect this strategy for change, civil society organizations must confront ageist attitudes and rethink the nature of work.

I opened this essay with a cinematic portrait of vigorous old age, and it may be appropriate to close with another, more recent film illustration. Commenting on his character in the controversial Oscar-winning film, Million Dollar Baby (2004), Clint Eastwood remarked that 70-plus fight manager
Frankie Dunn "was retired in his mind" before a fateful meeting with promising 32-year-old Ozarks boxer, Maggie Fitzgerald (Eastwood interviewed in Lipton, "Takes on Three", 2005). The movie is a parable of lost knowledge regained, generational mentoring, and mutual inspiration and reliance in the workplace struggle. It may form part of a transformed, and overdue, cultural understanding of age and work in the twenty-first century.

\section{David MacGregor}

Professor of Sociology

King's University College at the University of Western Ontario

\section{Notes}

1 For the purposes of this essay, the following is a useful definition of civil society organizations (CSOs):

Civil society actors include business forums, faith-based associations, labor movements, local community groups, non-governmental organizations (NGOs), philanthropic foundations, think tanks, and more...[P]olitical parties [are not included] as part of civil society, given thatunlike the other citizen groups just namedpolitical parties aim to occupy public office. [C]ommunications media also are not covered. (International Monetary Fund, 2003)

Although their attention to the subject is sporadic at best, communications media (e.g., newspapers, television, and radio) are more sympathetic to the claims of older workers than are most CSOs.

2 The government's legislation on mandatory retirement is currently under appeal before five law lords in a case involving two older male workers; see "Test Case on Redundancy Rights for Over 65s Goes to the Lords, $2006^{\prime \prime}$.

3 My colleagues C.T. Gillin and Thomas Klassen (2000) broke the long silence with a series of articles, including "Retire Mandatory Retirement"; see also, Gillin, MacGregor, \& Klassen, 2005.

4 However, the CCPA Monitor published this author's editorial on mandatory retirement (along with a rebuttal) in its December 2005/January 2006 issue; see MacGregor, 2005/2006.

\section{References}

Achenbaum, W.A. What is retirement for? (2006). Wilson Quarterly, 30(2). Retrieved 27 June 2006 from http:/ / www.wilsoncenter.org/index.cfm? fuseaction $=$ wq. essay\&essay_id=178668.

At 78, Bonnie Rooks likes a "dirty old job" in an Ohio steel mill. (2005, August 10). Wall Street Journal, p. A1. 
Butler, R.N. (1975). Why survive: Being old in America. Baltimore: John Hopkins University Press.

Canadian Centre for Policy Analysis. (2006). CCPA reports and studies. Retrieved 6 June 2006 from http://www.policyalternatives.ca/index.cfm? act $=$ main \&call $=\mathrm{A} 2286 \mathrm{~B} 2 \mathrm{~A} \& \mathrm{pa}=\mathrm{A} 2286 \mathrm{~B} 2 \mathrm{~A} \&$ type $=5 \&$ office_ID $=2,3,1,4,5,6 \&$ do $=$ list\&sr $=151$.

Canadian Federation for the Humanities and Social Sciences. (2006). Congress 2006. Retrieved 27 June from http:/ /www.fedcan.ca/congress2006/.

Dickason v. University of Alberta [1992] 2 S.C.R. 1103 (S.C.C.).

Eastwood, C. (Producer \& Director), \& Haggis, P. (Producer). (2004). Million dollar baby [Motion Picture]. United States: Warner Bros.

Fourzly, M., \& Gervais, M. (2004). Chapter 5: (Anti-)discrimination clauses and practices. Collective agreements and older workers in Canada. Retrieved 31 May 2006 from Social Development Canada web site: http://www.sdc.gc.ca/en/lp/spila/wlb/caowc/ 10chapter_5.shtml\#bnote4-.

Gillin C.T., \& Klassen, T. Retire mandatory retirement. (2000, July/August). Policy options. Retrieved 27 June 2006 from http://www.irpp.org/po/archive/jul00/ gillin.pdf.

Gillin, C.T., MacGregor, D., \& Klassen, T. (2005). Time's up: Mandatory retirement in Canada. Toronto: James Lorimer.

Hell, no-He won't go. (2006, May 4). Inside Higher Education. Retrieved 27 June 2006 from http://inside highered.com/layout/set/print/news/2006/05/04/ maryland.

International Monetary Fund. (2003). Definition: What is civil society? Guide for staff relations with civil society organizations. Retrieved 6 June 2006 from http:// www.imf.org/external/np/cso/eng/2003/ 101003.htm\#II.

Levine, M.L. (1988). Age discrimination and the mandatory retirement controversy. Baltimore: John Hopkins University Press.

Macafee, M. (2005). University of Winnipeg prof must take mandatory retirement for now. Canadian Press Newswire. Retrieved 25 Augutst 2006 from http:/ / www.recorder.ca/ cp/National/050817/n081799A.html.

MacGregor, D. (2005/2006). Yes, right to work is fundamental, even for people over 65. CCPA Monitor: Economic, Social, and Environmental Perspectives, 12(7), 24.

Marshall, L. (2006). Aging: A feminist issue. NWSA Journal, 18(1), vii-xiii.

McKinney v. University of Guelph, [1990] 3 S.C.R. 220 (S.C.C.).
New Brunswick Human Rights Commission. (2005). Guideline on mandatory retirement. Retrieved 27 June from http://www.gnb.ca/hrc-cdp/e/Guideline-onMandatory-Retirement.pdf.

Lipton, J. (2005). Takes on three [Interview with Clint Eastwood]. In C. Eastwood (Director \& Producer), \& P. Haggis (Producer), Million dollar baby (2-disk DVD widescreen ed.) [Special Features]. United States: Warner Bros.

Liscomb, V.B. (2006). "We need a theoretical base": Cynthia Rich, women's studies and ageism [ Interview with Cynthia Rich]. NWSA Journal, 18 (1), 3-12

Organisation for Economic Cooperation and Development. (2005). Ageing and employment policies: Canada. Paris: Author.

Saskatchewan Human Rights Tribunal. (2005, October 14). Decision regarding intervenor application. Retrieved 27 June from http://www.saskhrt.ca/forms/index/ Descisions/101405.htm.

Sixth International Conference on Diversity in Organisations, Communities and Nations. (2006). 2006 theme: Human rights, diversity and social justice. Retrieved 6 June 2006 from http://d06.cgpublisher.com/ themes.html.

Test case on redundancy rights for over $65 \mathrm{~s}$ goes to the Lords. (2006, March 6). Guardian. Retrieved 6 June 2006 from http://www.guardian.co.uk/law/story/ $0,1724385,00 \cdot h t m l$.

$\mathrm{U}$ of A rethinks policy on mandatory retirement. (2006, May 23). Edmonton Journal. Retrieved 5 June 2006 from http://www.canada.com/edmontonjournal/ news/story.html?id=7c55060f-4959-4072-a598-1f94f90c $28 \mathrm{~b} 2 \& \mathrm{k}=87997 \& \mathrm{p}=2$.

Visconti, L. (Producer \& Director). (1971). Death in Venice [Motion Picture]. United States: Warner Bros.

University of Alberta et al. (2005). Ian Whishaw. Biography. Retrieved 27 June 2006 from http://www.psych. ualberta.ca/GCPWS/kolb_whishaw.html.

Women's Legal and Education and Assistance Fund. (1999). Submissions to the Canadian Human Rights Review Panel, November 1999. Retrieved 6 June 2006 from http://www.leaf.ca/legal-pdfs/CHRAReview Submission99.PDF.

Women's Legal and Education and Action Fund. (n.d.[a]). Significant cases. Legal work. Retrieved 27 June from http:/ / www.leaf.ca/legal-cases.html

Women's Legal and Education and Action Fund. (n.d.[b]). No means no: Equality rights, responsibilities and the Charter. Teen pages. Retrieved 27 June from http:// www.leaf.ca/teen-no.html. 